\title{
Developing a Media to Teach Chemical Technology to Students with Hearing Impairments
}

\author{
Rila Muspita $^{1,2}$, Syihabuddin ${ }^{1 * *}$, Achmad Hufad $^{1}$, Asep Bayu Dani Nandiyanto $^{1 *}$, \\ Reno Fernandes ${ }^{2}$, Amin Akbar ${ }^{2}$, Tryastuti Irawati Belliny Manullang ${ }^{1}$, Rafikah Trinalia ${ }^{3}$ \\ ${ }^{1}$ Universitas Pendidikan Indonesia, Jl. Dr. Setiabudhi No. 229 Bandung, Indonesia \\ ${ }^{2}$ Universitas Negeri Padang, Jl. Prof. Dr. Hamka, Air Tawar Padang, Indonesia \\ ${ }^{3}$ SLBN Sungai Penuh, Jl. Depati Parbo, Sungai Penuh, Indonesia \\ 1rilamuspita@upi.edu, syihabuddin@upi.edu, achmadhufad@upi.edu,nandiyanto@upi.edu,manullang@upi.edu, \\ ${ }^{2}$ renofernandes@fis.unp.ac.id, aminakbar@fip.unp.ac.id \\ 3 trinaliarafikah@gmail.com
}

\begin{abstract}
This study aims to develop chemical technology learning media through the production of dishwashing soap using sign language for students with hearing impairments. This study used a six-step research method by Borg and Gall, namely needs analysis, planning, video validation, media testing, media revision, and testing the revised media. The results of this study indicate that to create audiovisual media, instrument validation is necessary. Validation of the instrument serves to verify the videos. After the videos are validated, the videos must be edited based on the experts suggestions until the videos are declared valid and ready to use. The videos are tested on eight students with hearing impairments to teach chemical technology and dishwashing soap making. The results of the main field experiments indicates that the experiments are ineffective because the tests conducted during the COVID-19 pandemic outbreak. Besides, learning for students with hearing impairments is generally conducted face-to-face and the media is accommodated by some learning aids for material delivery.

Keywords: Audio-visual, Chemical Technology, Hearing Impairment Media, Validity
\end{abstract}

\author{
Corresponding Author \\ * Departemen Pendidikan Kimia, Universitas \\ Pendidikan Indonesia, Jl. Dr. Setiabudhi No. 229 \\ Bandung, Indonesia \\ *nandiyanto@upi.edu \\ ** Departemen Pendidikan Bahasa Arab, Universitas \\ Pendidikan Indonesia, Jl. Dr. Setiabudhi No. 229 \\ Bandung, Indonesia \\ **syihabuddin@upi.edu
}

\section{Introduction}

Audio-visual media is no longer used in the midst of increasingly rapid technological developments. Children and adolescents spend most of their time using film media or watching television with an average of $2 \mathrm{~h} 46 \mathrm{~min}$ for each day at the age range of 2 to 18 years (Rideout, Foehr, Roberts, and Brodie, 1999). This includes students with hearing impairments who are involved in the use of video in daily life. In addition, the use of videos for students with hearing impairments helps to present information in a concrete way because the processes of conveying information must be concrete and contextual (Susialita, 2016).

The use of media to get students' attention is a common approach used by teachers (Hobbs, 2006). Videos can be used as a strategy to teach chemical technology to students with hearing impairments. The learning strategy is an action plan or a series of activities that include the use of various resources or strengths in learning (Majid, 2015).

Learning media for children with special needs designed based on the needs analysis of each student to support the delivery of the subject. Science learning media for children with special needs is specifically designed to develop their potential and abilities (Fajrie and Masfuah, 2018). In addition, learning media for children with hearing impairments is an essential communication channel for the learning process (Istanti and Triwidjaja, 2014). One of the principles of education for students with special needs is modelling (Utina, 2014).

Several studies on science on students with hearing impairments have been conducted such as the research on the design of multifunctional equipment technology for people with visual impairments and hearing impairments in plausible science practice (Pujianto, Astono, Rosana, and Purwanta, 2012). Furthermore, one of the findings is the ability of students to understand the concept of measurement is still limited to memory because science or science practicum are rarely conducted. Additionally, research on science learning media models for children with special needs is specifically designed to develop their potential and abilities (Fajrie and Masfuah, 2018). Meanwhile, research on the analysis of scientific literacy in students with hearing impairments on the concept of science, especially on the concept of solid and liquid forms, needs further research (Setyaningsih and Andajani, 2019).

Research using video media includes the effectiveness of video tutorial media on the skills of making lip balms for 
students with hearing impairments and the video is considered effective as a video tutorial (Elvida and Ardisal, 2018). Another research is on the development of interactive science video media for students with hearing impairments in which the designed video is declared valid by experts (Zahroh, Habibi, and Herowati, 2017). Development of Indonesian sign language learning videos (BISINDO) for students with hearing impairments that media that has been developed and designed attractively by combining pictures and words after being declared valid by experts can be used in learning (Anugerah, Ulfa, and Husna, 2020). As audiovisual media is designed to visualize understanding to students with hearing impairments. Visual and verbal cues that support understanding and retention of content by students with disabilities (Evmenova and Behrmann, 2011).

Teaching science to students with hearing impairments is much more challenging than to children with other barriers (Nandiyanto, Asyahidda, Danuwijaya, Abdullah, Amelia, Hudha, Aziz, 2018; Nandiyanto, Raziqi, Dallyono, and Sumardi, 2020; Maryanti, Hufad, Sunardi, Nandiyanto, and Al-Obaidi, 2020). This is because students with hearing impairments exhibit attention, poor interest, and lack of basic understanding (Im and Kim, 2014). Based on some of the aforementioned studies, science learning for people with hearing impairment need to special designed. Furthermore, the use of media for students with hearing impairments needs to be developed and validated. The experts are researchers who have studied the expertise and could validate accuracy of the products (Dieker, Lane, Allsopp, O'Brien, Butler, Kyger, and Fenty, 2009). Meanwhile, previous research did not show specific science learning about chemical technology using valid BISINDO sign language. So, it is necessary to develop an audiovisual media to teach chemical technology using sign language to students with hearing impairments until the media considered valid. The availability of valid learning videos that can be understood by students with hearing impairments could be used to build knowledge even though there are no professional instructors (Galindo-Neto, Alexandre, Barros, Sá, Carvalho, and Caetano, 2019).

\section{Logical Framework}

Media is a tool that conveys or delivers learning messages (Arsyad, 2019). Video media is classified as an audiovisual media that is capable of displaying information through images and sounds that are conveyed simultaneously. The advantages of audiovisual media are to communicating messages completely by showing objects, places, and events in a comprehensive motion picture format. Furthermore, the main characteristics of audio-visual media technology are linear, providing dynamic visuals, predefined by the designer, physical representations of real ideas or abstract ideas, developed according to the principles of psychological behavior, and oriented to the teacher with a low level of student interactive involvement (Pribadi, 2017).

One of the illustrations that serve as a guide for the use of media in the learning process is Dale's Cone of
Experience shown in Figure 1. A person's learning outcomes are obtained starting from direct experience (concrete), realities in the environment, through artificial objects, and verbal symbols (abstract). The higher the medium, the more abstract the medium for conveying the message. The order in the picture is not the sequence of the learning process and teaching and learning interactions. Concrete experiences and abstract experiences are experienced in turn.

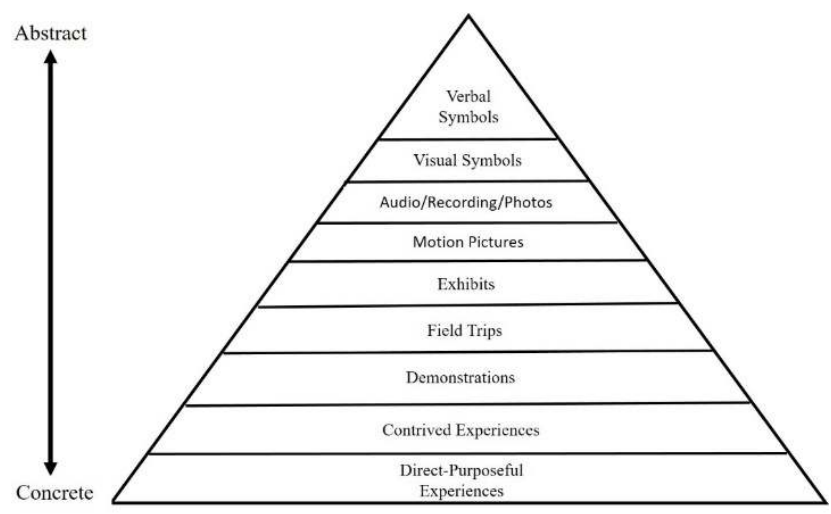

Fig. 1 Dale's Cone of Experience

The material teaches to students with hearing impairments is about chemical reactions in soap making. Dish soap is one of the applied chemical technologies. Figure 2 illustrates the chemical reactions in soap making. Soap is formed by the reaction between alkali oils that produce soap. The alkalis used are $\mathrm{NaOH}$ and $\mathrm{KOH}$ (Widyaningsih, Chasani, Diastuti, and Rahmayanti, 2019). The use of $\mathrm{KOH}$ produces a softer and more liquid soap (Sari, Kasih, and Sari, 2010). Alkaline salts from fatty acids are produced according to fatty acid reactions (Sukeksi, Sidabutar, and Sitorus, 2017). The soap formation reaction produces soap as the main product and glycerin as a side product (Fatoni and Fatimah, 2017).

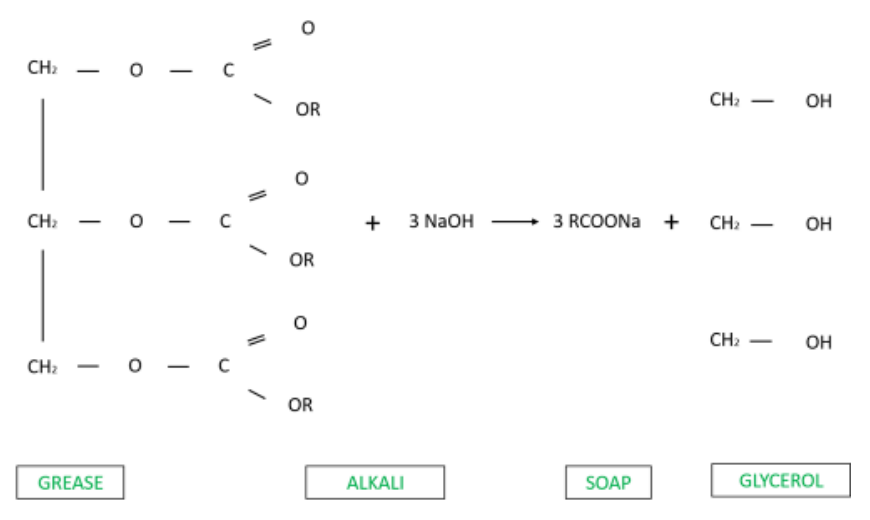

Fig. 2 Soap Formation Reaction

\section{Methods}

This study adopts the development of Borg and Gall (Borg and Gall, 1983). A model with ten steps as shown in Figure 3. This study only uses six steps of the Borg and Gall 
model which are the needs analysis, planning, video validation, media testing, media revision, and testing the revised media. This study only conducted until the main field testing due to the time limit. However, the next steps will be conducted promptly.

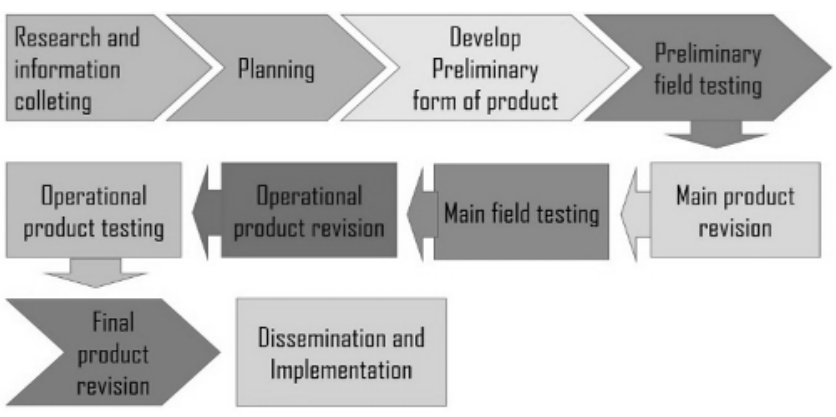

Fig. 3 Borg and Gall's Development Research Procedures

At the first stage, we conducted an analysis and then plan strategy by designing videos. At this planning, the scripts are compiled. Then, the storyboarding is created and after that, the videos are recorded. After the video production, the videos are edited. As the videos have been produced, the process continues to the next stage; media validation. The videos are validated by three experts consisting of a communication and media expert, a chemistry expert, and a special education expert. After the validation has been established, the videos are then tested on eight people with hearing impairments. Being based on the test and experts' validation, the videos are edited. Finally, valid videos are tested to eight students with hearing impairments.

\section{Results and Discussion}

\subsection{Analysis and Collection of Data Information}

The designed media is tested on eight people with hearing impairments aging from 20 to 50 years who are members of Movement for the Well-Being of Deaf Indonesians "Gerakan untuk Kesejahteraan Tunarungu Indonesia (GEKARTIN)". After media validation and revision, the videos are then tested to eight students with hearing impairments at secondary special school who have different academic abilities.

Videos are aimed at people with hearing impairments. Video can be addressed to large groups or small groups, heterogeneous groups, or individuals (Arsyad, 2019). Videos can be used for learning purposes, both for individual and group study purposes (Pribadi, 2017).

\subsection{Planning and Producing}

This audio-visual media is designed to teach chemical technology applied to everyday life with examples of soap making. This video consists of two parts. The first part contains chemical technology with simplified materials and the second part of the video teaches how to make dish soap as an example of a product of chemical technology used in everyday life. Both videos use the sign language used by people with hearing impairments in the community, namely Indonesian Sign Language or known as BISINDO. The choice of sign language is based on requests from people with hearing impairments in the community. Information provided to deaf people should be provided visually and explained with sign language aids (Swanwick, 2017).

\subsection{Validity of Instruments}

Video validation is important because the instrument is designed by the researchers, taking into account that the data that the researchers will take is specific to the needs of the conducted research. So, the standard instrument cannot be used. Validation is needed to help researchers determine instrument items (Burton and Mazerolle, 2011). The validity of the instrument is used to measure the items that should be measured (Misbach and Sumintono, 2014). Besides, a valid instrument will get valid data (Hidayati, 2011). The instruments are arranged based on every criterion, namely instruments for validating, instruments for communication, and media content, instruments for validating chemical theory content, and validating videos for special educational content.

The validated instruments have two improvements in each of the criteria. After testing the validity of the expert, the instruments are revised according to expert advice until it is declared valid (Yusup, 2018). In the instruments for special educational content, there are several important points suggested by experts, including clear operational instructions. There are several errors in writing the manuscript, one of which is operational instructions (Kurniawan, Kuswandi, and Husna 2018). Explanatory notes are placed under the table, the instrument consisted of numbers, items, and assessments without any indicators. Furthermore, instruments for content validation of chemical theory suggest that each item must use operational verbs. Instrument experts for communication and media content suggest that items on "video linkage, narration with the background music" should be carried out separately such as compatibility of narrative selection with video, and suitability of selection of background music with video. Cover quality items are described in attractive cover designs and complete information on the cover. Layout balance items are converted into proportional layouts or text and image layouts. Elements assessed in content validity such as operational, answer format, grammar, and writing layout (Yusup, 2018).

\subsection{Preliminary Field testing}

The initial testing phase is carried out on people with hearing impairments. The trial results obtained knowledge of chemical technology with an average of $90 \%$ and learning scores getting an average of $81 \%$. The obstacles experienced when answering questions only lie in the understanding of the theoretical concept because it is influenced by the impact of the barriers that students have. After watching the explanation video using sign language, the subject's knowledge of applied chemical technology has increased. Therefore, it can be concluded that video media could help 
people with hearing impairments in achieving knowledge and learning.

\subsection{Revision as Validator Suggestion}

The video validator consists of three experts includes a communication and media expert, an expert in chemistry, and a special education expert. Figure 4 displays the twovideo data on the first validation. In video I, the media communication expert gives $69 \%$ for the video media and states that the video media could be used with improvement. Suggestions are given on the improvement of the subtitles where some parts of the sentence are ineffective, the bumper in and bumper out need editing. Furthermore, the communication and the media validator mentioned that the cues and subtitles do not have conjunction. In the video, the sign language used is BISINDO which does not have signs for conjunction. Sign language cannot accommodate a lot of vocabulary, which causes the word collection of students with hearing impairment to be limited which causes students' understanding of a concept is hampered (Hall, 2017).

In video II, the communication and media expert gives $60 \%$ which is lower than the video I. In video II there are many shortcomings compared to the video I, including the quality of the opening and closing videos, which are less attractive, the quality of editing is poor, the size of the subtitles is tiny which shows imbalance with the video space, then the bumper in and the bumper out is absent. A bumper is a short animation that functions as a marker for starting or ending a program. Before entering the main part of the video, a bumper is made (Algiffari, 2015). Bumpers can also affect the sensation of human perception and could influence the audience (Adi, 2020).

The chemistry expert in Figure 4 rated video I at $62 \%$ and suggests some improvements on the soap formation reactions, examples of chemical technology, and identification of the soap types. While in video II the value reaches $83 \%$ with improvements in the explanation of the materials used, clarity of the function of the materials used, and in video II the manufacturing reaction is still shown as in video I. The chemistry expert stated that the video could be used with some improvement. Furthermore, Figure 4 displays special education expert and also gives some suggestions, namely the appropriateness of the perception and the opening is too fast. So, it is necessary at the beginning to do the editing again. Meanwhile, in video II with a value of $84 \%$, the expert suggests that if the videos show any information on the times or days difference, it is necessary to differentiate the costumes used in the video as a sign that the activities are conducted on different days. Furthermore, special education expert also suggests that video II use visualization of the activity so the video would provide productivity values for students with hearing impairments. Learning to students with hearing impairments should raise productivity values (Muspita, Safaruddin, Ardisal, and Sopandi, 2018). From these comments, the two videos could be used with improvement.

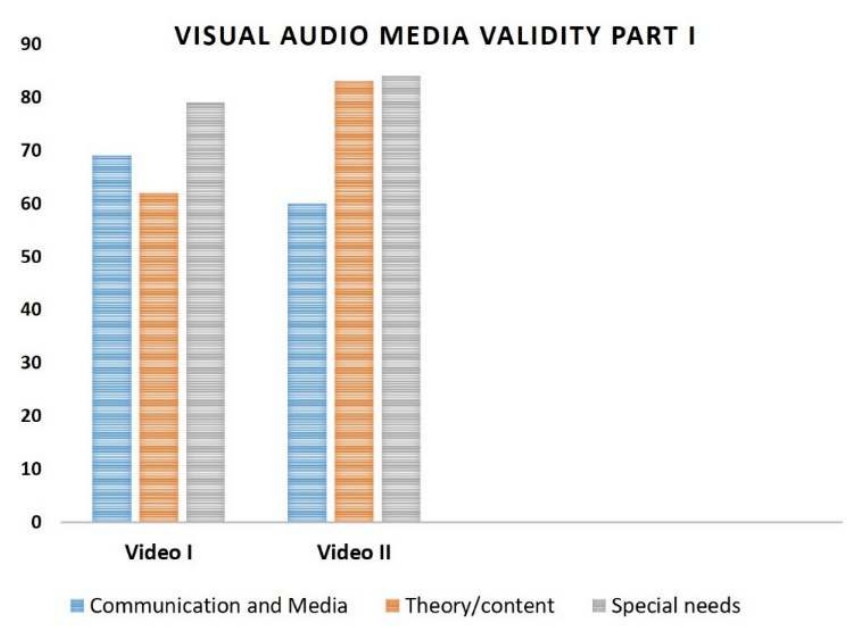

Fig. 4 Visual Audio Media Validity Part I

After the videos are edited based on the suggestions s, the two videos are given again to the three experts for validation so they could ensure that the two videos are valid and usable. The assessment results are shown in Figure 5. In Figure 5, communication and media expert rated $89 \%$ for the video I and $91 \%$ for video II, while chemistry or theory expert scored video I $87 \%$ and $91 \%$ for video II. Then, the special education expert gave $93 \%$ for the video I and video II. The three experts stated that the video can be used without improvement or the videos declared as valid. After the videos have been validated, the videos are then tested to teach chemical technology to students with hearing impairments.

\section{VISUAL AUDIO MEDIA VALIDITY PART II}

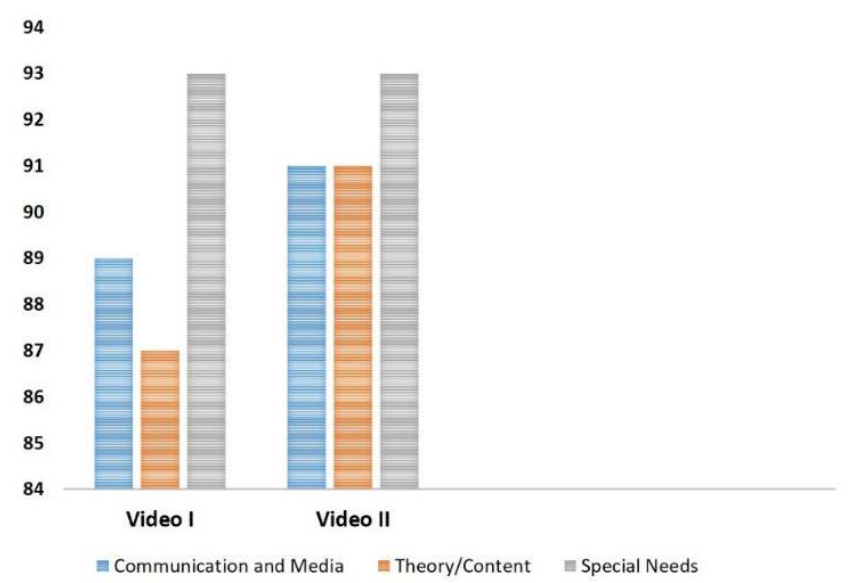

Fig. 5 Visual Audio Media Validity Part II

\subsection{Main Field testing}

The next trial is conducted on eight students with hearing impairments with different academic abilities. The media trials are conducted by online due to COVID-19 pandemic outbreak. The first step is conducted by given a pretest about knowledge and understanding. After the pretest results collected, students watched two videos about chemical 
technology and dish soap making. After watching the videos, students did the posttest. However, out of eight students, only one student did the posttest. The other seven students did not want to do the posttest due to some barriers including shortage of internet data package, the low understanding of the materials being studies, and requesting to do it during face-to-face learning. In learning, it is not only limited to teacher being able to design the appropriate media. Besides, teachers should be creative to select and use good material for the students (Kurniawan, 2016). However, other factors such as unexpected natural disasters affect the learning process.

Needless to say, that experiment at the main field-testing stage is ineffective because learning for students with hearing impairments is generally carried out face-to-face and supplied by some learning/teaching aids for material delivery. Ideally, learning should be conveyed directly and with the help of visual media (Suarsana, Mahayukti, Sudarma, and Yoga, 2018). Furthermore, as for the main field-testing, it is necessary to consider the condition of the students with hearing impairment and observe their readiness to study.

\section{Conclusion}

The results of this study show that in order to create audiovisual media or video, a series of validation activities are necessary to make the video accessible and valid. Some of these steps, include instruments and video validation. After the instruments have been declared valid, the instruments are ready to and then given to the experts for validating the next media; the videos. Next, the validated video must be edited and improves based on the expert's suggestions until it is declared valid and ready to use. The valid videos then can be tested to teach chemical technology and dishwashing soap making to students with hearing impairments. However, the media experiments at the main field-testing stage are ineffective because learning for students with hearing impairments usually happens in a face-to-face situation and accommodated by some learning aids for material delivery. The limitation of this research is that the sign language used in the video uses BISINDO. Meanwhile, BISINDO does not have sign language for conjunctions which resulting in limited vocabulary in the explanation. Furthermore, the main field-testing data collection is conducted during the pandemic which makes it ineffective.

\section{Acknowledgements}

We would like to acknowledge Sekolah Pasca Sarjana Universitas Pendidikan Indonesia and Universitas Negeri Padang for supporting this research. We would also like to thanks all expert validator and SLBN Sungai Penuh for assisting this experiment. We also thank to Ristek BRIN (grant in aid: Penelitian Terapan Unggulan Perguruan Tinggi) and Bangdos Universitas Pendidikan Indonesia.

\section{References}

Adi, P. S. (2020). LKP: Perancangan Bumper dan Video Tutorial Software the Payment Pembayaran SPP pada CV.
Komputerkit (Doctoral dissertation, Universitas Dinamika). Hal. 31-66

Algiffari, M. (2015). Perancangan motion graphic (bumper in) dan video dokumenter permainan tradisional Jawa Barat (analisis deskriptif permainan tradisional pada Sanggar Seni Tikukur Majalengka). Jurnal Sketsa, 2(1), 1-13.

Anugerah, S. Y., Ulfa, S., and Husna, A. (2020). Pengembangan Video Pembelajaran Bahasa Isyarat Indonesia (Bisindo) Untuk Siswa Tunarungu Di Sekolah Dasar. JINOTEP (Jurnal Inovasi dan Teknologi Pembelajaran): Kajian dan Riset Dalam Teknologi Pembelajaran, 7(2), 76-85.

Arsyad, A. (2019). Media Pembelajaran. Depok: Rajagrafindo Persada.

Borg. W.R and Galll. M.D. 1983. Educational Research: An Introduction. New York: Longman

Burton, L. J., and Mazerolle, S. M. (2011). Survey instrument validity part I: Principles of survey instrument development and validation in athletic training education research. Athletic Training Education Journal, 6(1), 27-35.

Dieker, L. A., Lane, H. B., Allsopp, D. H., O'Brien, C., Butler, T. W., Kyger, M., ... and Fenty, N. S. (2009). Evaluating video models of evidence-based instructional practices to enhance teacher learning. Teacher Education and Special Education, 32(2), 180-196.

Elvida, R., and Ardisal, A. (2018). Efektivitas Media Video Tutorial terhadap Keterampilan Membuat Lip Balm bagi Tunarungu. Jurnal Penelitian Pendidikan Khusus, 6(2), 172177.

Evmenova, A. S., and Behrmann, M. M. (2011). Based strategies for teaching content to students with intellectual disabilities: Adapted videos. Education and Training in Autism and Developmental Disabilities, 46(3), 315-325.

Fajrie, N., and Masfuah, S. (2018). Model Media Pembelajaran Sains untuk Anak Berkebutuhan Khusus. Bagimu Negeri: Jurnal Pengabdian Kepada Masyarakat, 2(1), 9-19.

Fatoni, R., and Fatimah, S. (2017). Pengembangan Ekonomi Kreatif Melalui Pembuatan Sabun Cair; Sebuah Upaya Pemberdayaan Anggota Aisyiah Di Wilayah Solo Raya. Proceeding The $6^{\text {th }}$ University Research Colloquium, Magelang: 9 September 2017. Hal. 149-152

Galindo-Neto, N. M., Alexandre, A. C. S., Barros, L. M., Sá, G. G. D. M., Carvalho, K. M. D., and Caetano, J. Á. (2019). Creation and validation of an educational video for deaf people about cardiopulmonary resuscitation. Revista latinoamericana de enfermagem, 27(1), 1-12

Hall, W. C. (2017). What you don't know can hurt you: The risk of language deprivation by impairing sign language development in deaf children. Maternal and Child Health Journal, 21(5), 961-965. 
Hidayati, K. (2011). Validasi Instrumen Non Tes dalam Penelitian Pendidikan Matematika. Prosiding Jurusan Pendidikan Matematika FMIPA UNY, Yogayakarta: 28 Februari 2011. Hal. 503-511

Hobbs, R. (2006). Non - optimal uses of video in the classroom. Learning, media and technology, 31(1), 35-50.

Im, S., and Kim, O. J. (2014). An approach to teach science to students with limited language proficiency: In the case of students with hearing impairment. International Journal of Science and Mathematics Education, 12(6), 1393-1406.

Istanti, A. W., and Triwidjaja, H. A. (2014). Penerapan Model Pembelajaran Picture and Picture Pada Pembelajaran Ipa Anak Tunagrahita SDLB. Jurnal Penelitian dan Pengembangan Pendidikan Luar Biasa, 1(2), 169-174.

Kurniawan, D. C., Kuswandi, D., and Husna, A. (2018). Pengembangan media video pembelajaran pada mata pelajaran IPA tentang sifat dan perubahan wujud benda kelas IV SDN Merjosari 5 Malang. JINOTEP (Jurnal Inovasi Dan Teknologi Pembelajaran) Kajian Dan Riset Dalam Teknologi Pembelajaran, 4(2), 119-125.

Kurniawan, F. (2016). The use of audio visual media in teaching speaking. English Education Journal, 7(2), 180193.

Majid, A., (2015). Strategi Pembelajaran. B andung: Remaja Rosdakarya

Maryanti, R., Hufad, A., Sunardi, S., Nandiyanto, A. B. D., and Al-Obaidi, A.S.M. (2020). Understanding covid-19 particle contagion through aerosol droplets for students with special needs. Journal of Engineering Science and Technology, 15(3), 1909-1920.

Misbach, I. H., and Sumintono, B. (2014). Pengembangan dan validasi instrumen "persepsi siswa tehadap karakter moral guru" di Indonesia dengan model Rasch. Prosiding Seminar Nasional Psikometri, Solo, Indonesia: 24 May 2014. Hal. 1-17

Muspita, R., Safaruddin, S., Ardisal, A., and Sopandi, A. A. (2018). Pembelajaran Keterampilan Membuat Ikan Bakar Bagi Anak Hambatan Pendengaran. Jurnal Pendidikan Kebutuhan Khusus, 2(2), 48-50.

Nandiyanto, A. B. D., Asyahidda, F. N., Danuwijaya, A. A., Abdullah, A. G., Amelia, N., Hudha, M. N., and Aziz, M. (2018). Teaching "nanotechnology" for elementary students with deaf and hard of hearing. Journal of Engineering Science and Technology, 13(5), 1352-1363.

Nandiyanto, A. B. D., Raziqi, G. Y., Dallyono, R., and Sumardi, K. (2020). Experimental Demonstration for Enhancing Vocational Students' Comprehension on Heat Transfer through Conduction and Radiation of Light Bulb. Journal of Technical Education and Training, 12(3), 189195.

Pribadi, B. A. (2017) Media dan Teknologi dalam Pembelajaran. Jakarta: Prenada Media
Pujianto, P., Astono, J., Rosana, D., and Purwanta, S. A. (2012). Rancang Bangun Teknologi Multifunction Equipment Bagi Penyandang Tuna Netra Dan Tuna Rungu Dalam Praktikum Sains Realistik. Jurnal Kependidikan: Penelitian Inovasi Pembelajaran, 42(2), 187-194.

Rideout, V. J., Foehr, U. G., Roberts, D. F., and Brodie, M. (1999). Kids and media@ the new millennium. Menlo Park, CA: Kaiser Family Foundation.

Sari, T. I., Kasih, J. P., and Sari, T. J. N. (2010). Pembuatan sabun padat dan sabun cair dari minyak jarak. Jurnal Teknik Kimia, 17(1), 28-33.

Setyaningsih, F., and Andajani, S. J. (2019). Analisis Literasi Sains Pada Siswa Tunarungu Terhadap Konsep IPA. Jurnal Pendidikan Khusus, 12(3), 1-9.

Suarsana, I. M., Mahayukti, G. A., Sudarma, I. K., and Yoga, I. N. B. A. (2018). Development of interactive mathematics learning media on statistics topic for hearing-impaired student. International Research Journal of Engineering, IT and Scientific Research, 4(6), 55-66.

Sukeksi, L., Sidabutar, A. J., and Sitorus, C. (2017). Pembuatan Sabun dengan Menggunakan Kulit Buah Kapuk (Ceiba petandra) sebagai Sumber Alkali. Jurnal Teknik Kimia USU, 6(3), 8-13.

Susialita, T. (2016). The development of audio-visual student portfolios (LKS) contextual teaching and learningbased (CTL) on sound chapter of science subject for deaf students. Jurnal Pendidikan IPA Indonesia, 5(2), 192-198.

Swanwick, R. (2017). Translanguaging, learning and teaching in deaf education. International Journal of Multilingualism, 14(3), 233-249

Utina, S., S. (2014). Pendidikan Anak Berkebutuhan Khusus. Jurnal Manajemen Pendidikan Islam, 2(1): 72-78.

Widyaningsih, S., Chasani, M., Diastuti, H., and Rahmayanti, E. (2019). The storage time on the characteristic of liquid dishwashing liquid from nyamplung seed oil (Calophyllum inophyllum L) and its antibacterial activity. In IOP Conference Series: Materials Science and Engineering. 509(1), 1-7.

Yusup, F. (2018). Uji validitas dan reliabilitas instrumen penelitian kuantitatif. Tarbiyah: Jurnal Ilmiah Kependidikan, 7(1), 17-23.

Zahroh, F., Habibi, H., and Herowati, H. (2017). Pengembangan Media Video Sains Interaktif Untuk Siswa Slb Tunarungu. Alpen: Jurnal Pendidikan Dasar, 1(2), 5468. 